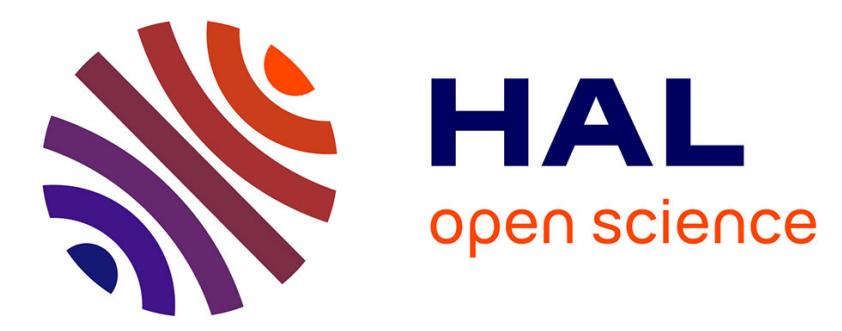

\title{
A Sculpted Dish from Tello Made of a Rare Stone (Louvre-AO 153)
}

François Desset, Gianni Marchesi, Massimo Vidale, Johannes Pignatti

\section{To cite this version:}

François Desset, Gianni Marchesi, Massimo Vidale, Johannes Pignatti. A Sculpted Dish from Tello Made of a Rare Stone (Louvre-AO 153). Journal of Near Eastern Studies, 2016, 75 (1), pp.71-84. 10.1086/684811. hal-03471079

\section{HAL Id: hal-03471079 https://hal.science/hal-03471079}

Submitted on 8 Dec 2021

HAL is a multi-disciplinary open access archive for the deposit and dissemination of scientific research documents, whether they are published or not. The documents may come from teaching and research institutions in France or abroad, or from public or private research centers.
L'archive ouverte pluridisciplinaire HAL, est destinée au dépôt et à la diffusion de documents scientifiques de niveau recherche, publiés ou non, émanant des établissements d'enseignement et de recherche français ou étrangers, des laboratoires publics ou privés. 


\title{
A Sculpted Dish from Tello Made of a Rare Stone (Louvre-AO 153)
}

\author{
FranÇOIS DESSET, UMR 7041 / University of Teheran* \\ GIANNI MARCHESI, University of Bologna \\ Massimo Vidale, University of Padua \\ Johannes PignatTi, "La Sapienza” University of Rome
}

\section{Introduction}

A fragment of a sculpted stone dish from Tello (ancient Girsu), which was found in the early excavations directed by Ernest de Sarzec, has been as studied by us in the frame of a wider research project on artifacts made of a peculiar dark grey limestone spotted with white-to-pink fossil corals of the genus Waagenophyllum. Recorded in an old inventory of the Louvre, the piece in question has quite surprisingly remained unpublished until now.

The special points of interest to be addressed here are: the uncommon type of stone, which was presumably obtained from some place in Iran; the finely carved lion image that decorates the vessel; and the mysterious iconographic motif that is placed on the lion's shoulder. A partially preserved Sumerian inscription, most probably to be attributed to the famous ruler Gudea of Lagash, should also be noted. ${ }^{1}$

\footnotetext{
* This artifact was generously brought to our attention by Beatrice André and Ariane Thomas, respectively Director of the Department of Near Eastern Antiquities and Curator of the Mesopotamian Section of the Louvre. The pictures (Figs. 1-2, 5-6, and 8-11) were taken by Edoardo Loliva (Istituto Superiore per la Conservazione e il Restauro, Rome). We would like to express our gratitude to all of them. The abbreviations used in this article are those of The Assyrian Dictionary of the Oriental Institute of the University of Chicago (Chicago, 1956-2010).
}

Close formal and stylistic comparisons with other artifacts of the same period from Tello make it clear that Waagenophyllum limestone, stemming probably from some Iranian source, was imported to Girsu to be locally carved in Sumerian style in the palace workshops. Mesopotamian objects made of this rare stone provide another element for reconstructing the patterns of material exchange between southern Mesopotamia and the Iranian Plateau in the late 3rd millennium BC.

\section{The Artifact}

We owe the first description of this dish fragment (Figs. 1-3), which bears the museum number AO 153, to Léon Heuzey:

Une disposition semblable, mais dans des proportions beaucoup plus petites, se voit au pourtour d'un élégant plateau circulaire, dont il ne reste aussi qu'un fragment. Seulement, comme le rebord n'a qu'une très faible élévation, le lion, dont la tête fait saillie, y était représenté couché. Il devait y en avoir trois ou quatre; mais il ne reste que la partie antérieure de l'un d'eux. Sur

\footnotetext{
${ }^{1}$ See G. Marchesi, "Gudea and the Master of Lions: Philological Notes on the Louvre Dish AO 153," in this issue of JNES.
} 

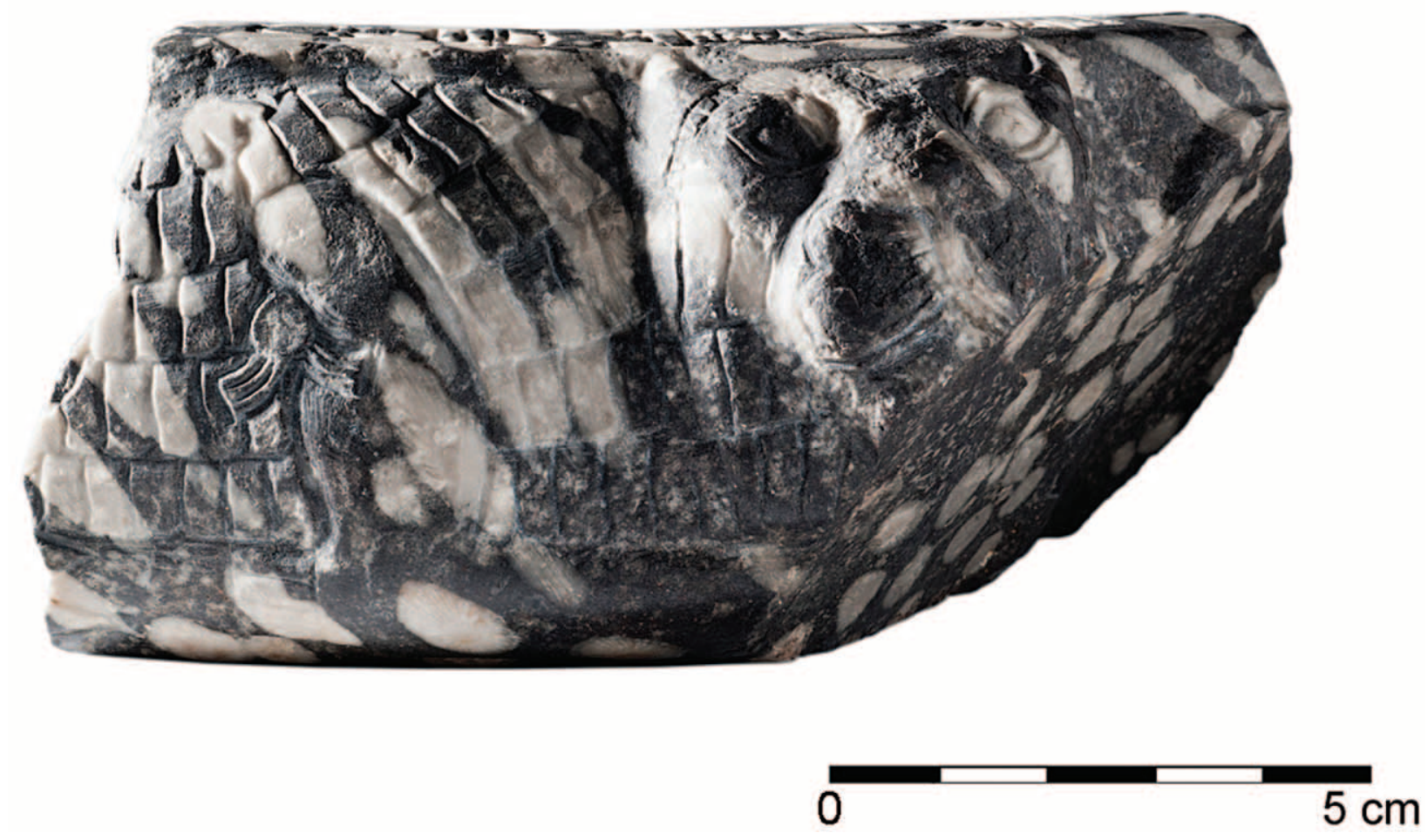

Figure 1-The stone dish AO 153 - general view of the outer surface (photo E. Loliva; courtesy Musée du Louvre).

le plat du rebord, un débris d'inscription, en caractères élégants et un peu allongés, de l'époque de Dounghi, indique que ce bel objet avait été consacré "pour la prolongation de la vie" d'un prince, dont le nom manque. La matière, dont un autre petit éclat a été recueilli, est d'une rareté exceptionnelle; c'est une sorte de marbre d'un bleu ardoise, moucheté et comme étoilé de blanc, par des perforations madréporiques. ${ }^{2}$

Fig. $4 \mathrm{~b}$ shows our reconstruction of the dish from the surviving fragment $(14 \times 12 \times 6 \mathrm{~cm})$. Its diameter at the rim was about $36 \mathrm{~cm}$, and the wall is about 6 $\mathrm{cm}$ high. The estimated diameter would have accommodated six lions of the same size as the one preserved along the circumference of the vessel. ${ }^{3}$ This reconstruction is based on the AutoCAD rotatory model

${ }^{2}$ E. de Sarzec and L. Heuzey, Découvertes en Chaldée (Paris, 1884-1912), 232. See also L. Heuzey, Catalogue des antiquités chaldéennes: Sculpture et gravure à la pointe (Paris, 1902), 159, no. 40; A. Parrot, Tello: Vingt campagnes de fouilles (1877-1933) (Paris, 1948), 196; E. A. Braun-Holzinger, Mesopotamische Weihgaben der frübdynastischen bis altbabylonischen Zeit, Heidelberger Studien zum Alten Orient 3 (Heidelberg, 1991), 183, G 334.

${ }^{3}$ Six lions in a row also occur on the famous mace-head of Mesalim, dedicated to the patron god of Girsu, Ningirsu; see de Sarzec seen in Fig. 4a. ${ }^{4}$ The animals were probably carved in a single row: beside the head of the preserved figure, one sees what is left of the curved tail of the preceding feline, and the circumference exactly fits the arc occupied by six lions. ${ }^{5}$

The wall of the plate is thick and sturdy, and the inner base is convex. For some reason, the inner surface of the fragment has a peculiar rough texture, which contrasts with the highly polished look of the outer surface and the lower base. Judging from what remains of the plate, a stone block with vertical fossils was cut transversally to the main axis of the coral's columnar growth, so that the coral calices on the base look like regularly-spaced round spots, whereas along

and Heuzey, Découvertes, 223-24 and pl. ${ }^{\text {ter }}$, no. 2; U. MoortgatCorrens, La Mesopotamia (Torino, 1989), 57.

${ }^{4}$ I.e., a drawing, in AutoCAD, of the surviving part of the dish, rotated to fit exactly the geometry of the original unbroken artifact. We owe the model and the reconstruction here proposed to A. Cherubini, an architect specializing in archaeological recording and reconstructions.

${ }^{5}$ The preserved fragment demonstrates that at least two lions were in a row in the same posture. Our reconstruction assumes that six felines crouched one after the other in the same direction, but we cannot exclude other arrangements. 


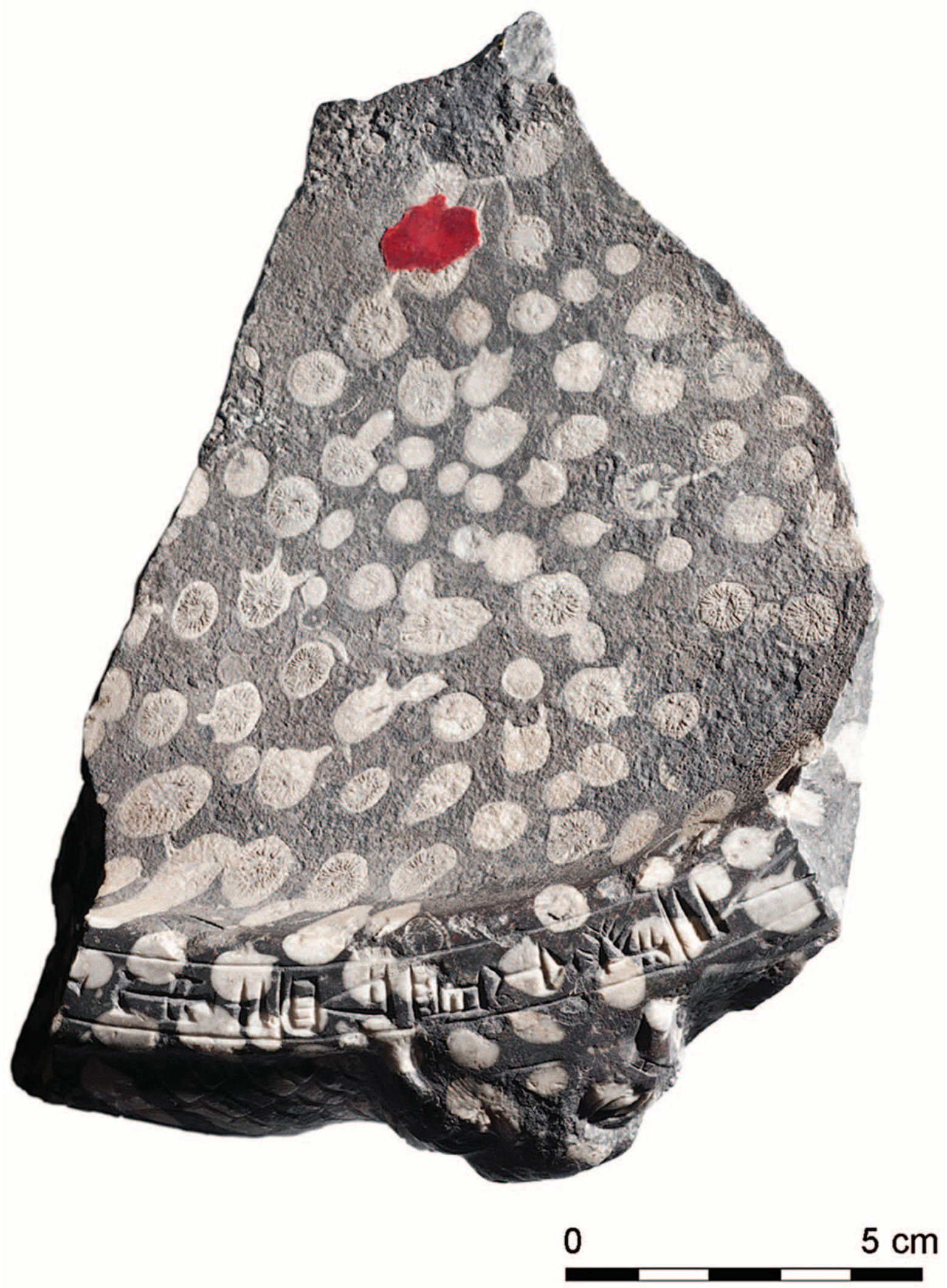

Figure 2-AO 153-zenithal view of the inner surface (photo E. Loliva; courtesy Musée du Louvre). 

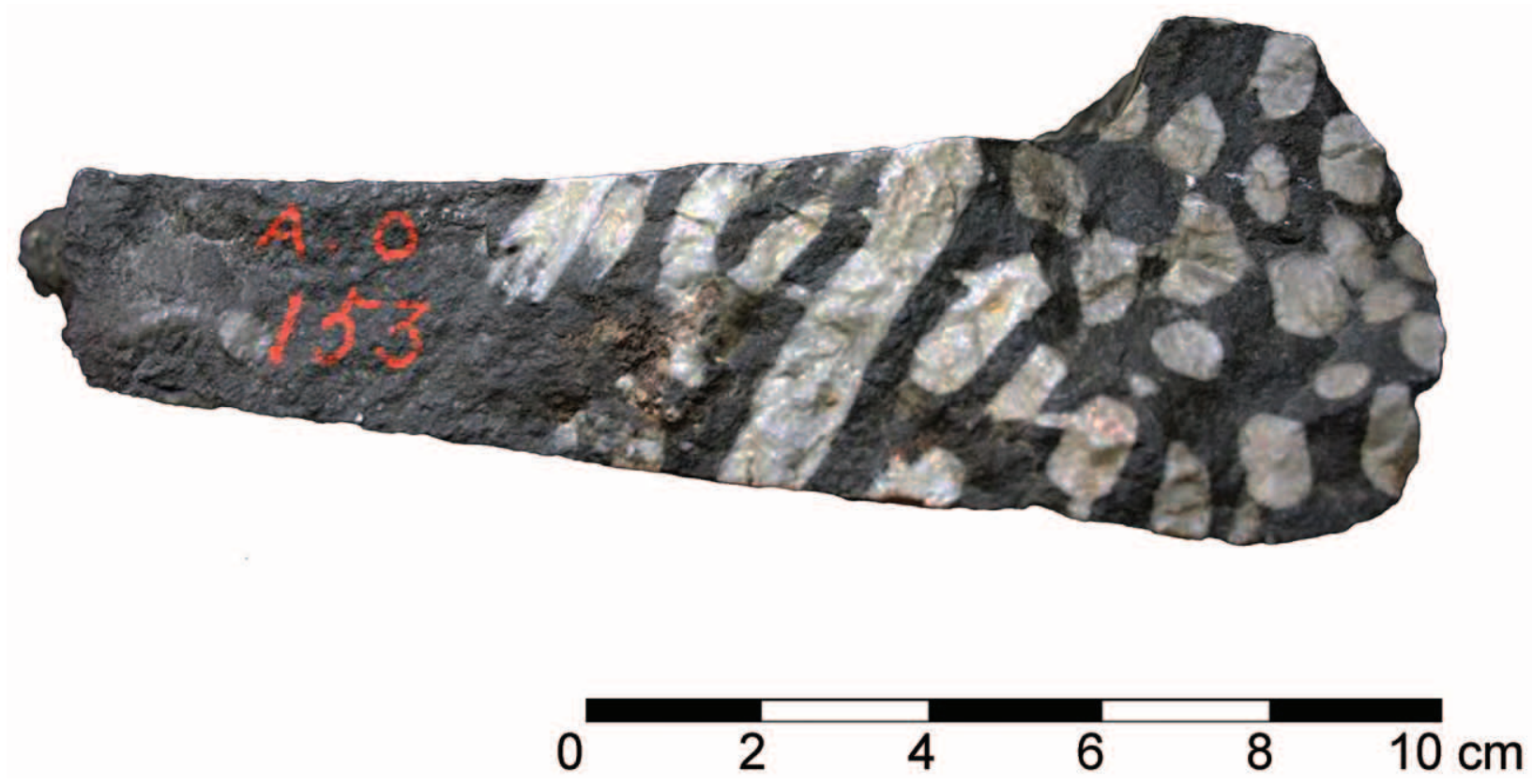

Figure 3-AO 153 - section (photo M. Vidale; courtesy Musée du Louvre).

the walls, and on the bodies of the felines, the same fossils take the form of short, thick wavy stripes. ${ }^{6}$

The carving shows a good balance between strongly stylized forms and naturalistic rendering. Only the lion's head, turned right, is in high relief. The back and the shoulder of the animal, in bas-relief, look powerful and muscular, thanks to the careful carving of the mane, which is divided into five rows of slightly S-shaped rectangles representing as many tufts. The body's volume is well suggested by the upward bending of the upper rows. The lion, portrayed with closed jaws, turns directly onward to face the viewer in a peaceful attitude. ${ }^{7}$ The muzzle (Fig. 5) is rendered in a simple but elegant fashion: here, note the triangular tip of the nose, and the symmetry of the two sides of the muzzle, whose lines close into two palmette-like features (poorly pre-

${ }^{6}$ Although Marco Polo relates to have seen, at the court of the Khan, large cats with white, black and red stripes, which were "maggiori de' leoni di Babilonia" (Il Milione, ch. XIV), adult lions have a uniform fur, without stripes or any other contrasting pattern. Marco Polo's striped lions were in all likelihood tigers. The white vertical stripes created by the corals on the lions of our dish have therefore no zoological correspondence, but stripes might have added to the fantastic nature of the sculpted felines.

${ }^{7}$ Compare the lions of the so-called Burney Relief (Fig. 12, No. 5; after D. Collon, The Queen of the Night [London, 2005], 6, fig. $1+32$, fig. 12), which according to D. Collon, "look outwards, proud, on guard, alert and apparently fully in control" (ibid., 35). served) that synoptically represent the whiskers (vibrissae), and the rows of small dots at their bases, which are typical of large cats. The staring eyes are carefully incised with a thin double line, and the sloping forehead interrupts a deeply-carved band (visible below the ears), hatched with transversal segments, which has no anatomical reference. From the rear of the forelimb departs another thick tuft of fur. The curved surface of the forelimb suggests the volumes of the muscles, while on the fracture, at the left, there is an element in the shape of tip (the lion's penis?).

Finally, the enigmatic circular element with appended wing-like features on the rear shoulder of the lion should be noted (Fig. 6). For this iconographic motif, which is also found elsewhere, see the discussion below (pp. 80-84).

\section{The Stone}

The base material of AO 153 can be identified as a Permian dark grey limestone rich in white fossil colonial tetracorals, belonging to the order Rugosa and the genus Waagenophyllum, named after the German geologist and palaeontologist Wilhelm Heinrich Waagen (1841-1900), who was active in British India from 1870 to 1875 . Outcrops of this rare material were identified at various locations on the Iranian Plateau, 


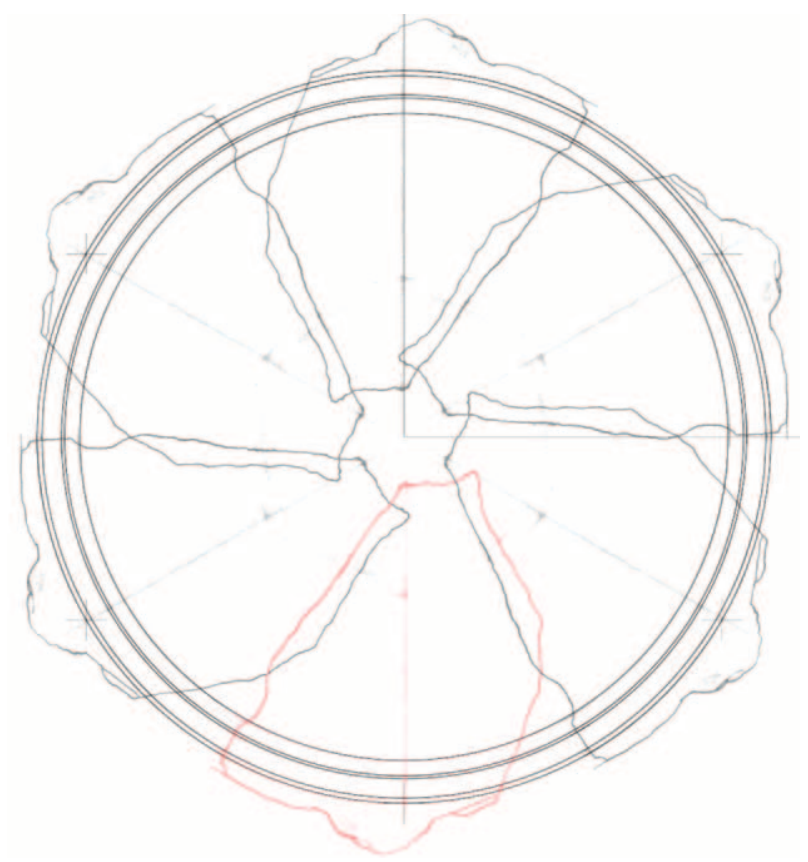

Figure 4a-Rotatory model based upon the surviving shard, supporting the reconstruction of Fig. $4 \mathrm{~b}$ (A. Cherubini and M. Vidale).

along the coasts of the Gulf, and in the inner Oman peninsula. However, the few specimens that have been recovered in Mesopotamia almost certainly came from the region of Kerman, in southeastern Iran, ${ }^{8}$ which was known in 3rd millennium cuneiform sources as Marhaši (Sumerian) or Parahšum (Akkadian). ${ }^{9}$

This kind of limestone is especially characterized by attractive contrasting patterns (as revealed by carving) and the physical homogeneity of these with their

${ }^{8}$ M. Vidale et al., "Waagenophyllum Coral Limestone: Another Article of Long-Distance Trade between the Iranian Plateau and Southern Mesopotamia in the Late 3rd Millennium B.c.," paper presented at the workshop "Shahdad and the Bronze Age in Southeast Iran," University of Cambridge, July 2011. While the employment of Waagenophyllum coral limestone is well-attested in 3rd millennium Iranian sites of the Kerman province such as Shahdad, Konar Sandal (Jiroft), and Tepe Yahya, only one single artifact made of this stone has instead been found in the Gulf area - a cylindrical vessel recovered in Tarut (ancient Tilmun), which is probably an import from southeastern Iran; see Routes d'Arabie: Archéologie et histoire du royaume d'Arabie Saoudite, ed. A. I. Al-Ghabban et al. (Paris, 2010), 193, no. 42.

${ }^{9}$ See, most recently, P. Steinkeller, "Marhaši and Beyond: The Jiroft Civilization in a Historical Perspective," in "My Life is like the Summer Rose." Maurizio Tosi e l'Archeologia come modo di vivere: Papers in Honour of Maurizio Tosi for His 70th Birthday, ed. C. C. Lamberg-Karlovsky, B. Genito, and B. Cerasetti, BAR International Series 2690 (Oxford, 2014), 691-707.

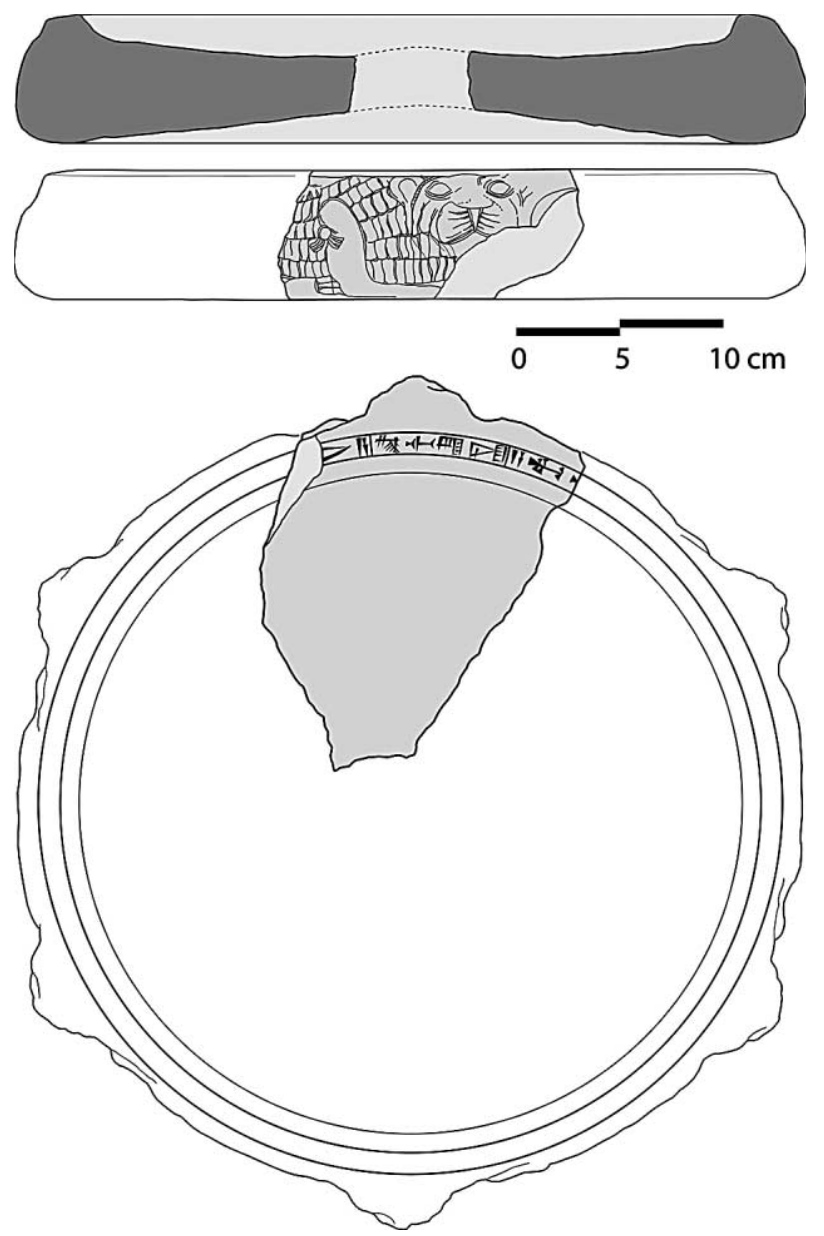

Figure $4 \mathrm{~b}-$ Reconstruction of the stone dish AO 153 (drawing M. Vidale and F. Desset).

darker matrix. In spite of their different colors and texture, their hardness and porosity were apparently the same, so that the sculpted and polished surfaces do not show any scar or gap.

Whereas the sourcing of the outcrops of this stone in southern Middle Asia, the history of its exploitation, and the name given to it in ancient cuneiform texts will be matter for a future publication, we may anticipate that its procurement, trade, and fashioning for centuries linked some southern Mesopotamian cities with contemporary centers of the Iranian Plateau. Waagenophyllum coral limestone, therefore, is ready to find a precise historical role in this framework along with chlorite rocks, diorite, alabaster, carnelian, lapis lazuli, and other ornamental or semiprecious stones that were traded between Mesopotamia and other Middle Asian civilization cores in the 4th and the 3rd millennia $\mathrm{BC}$. 


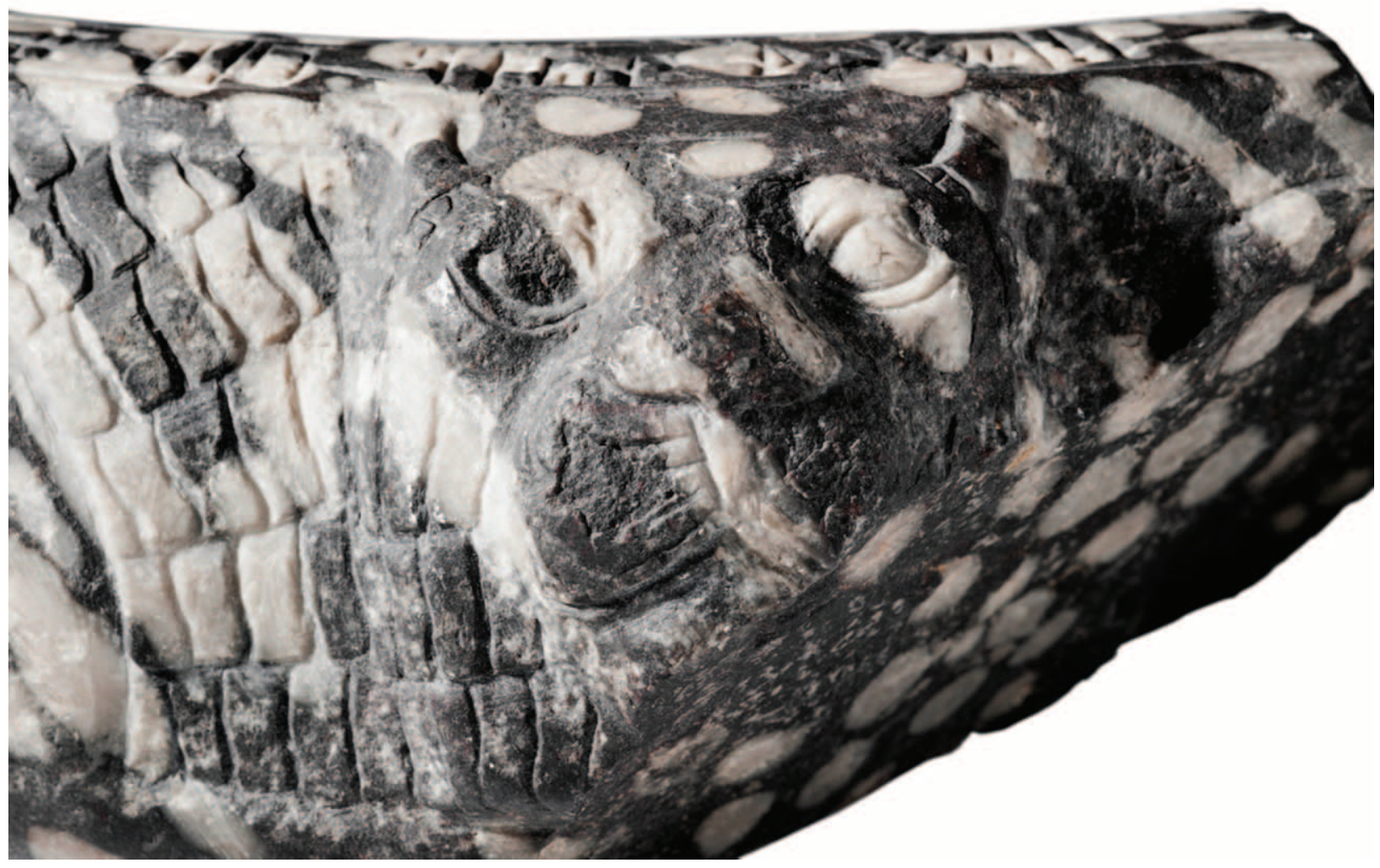

Figure 5-AO 153-detail of the lion's muzzle (photo E. Loliva; courtesy Musée du Louvre).

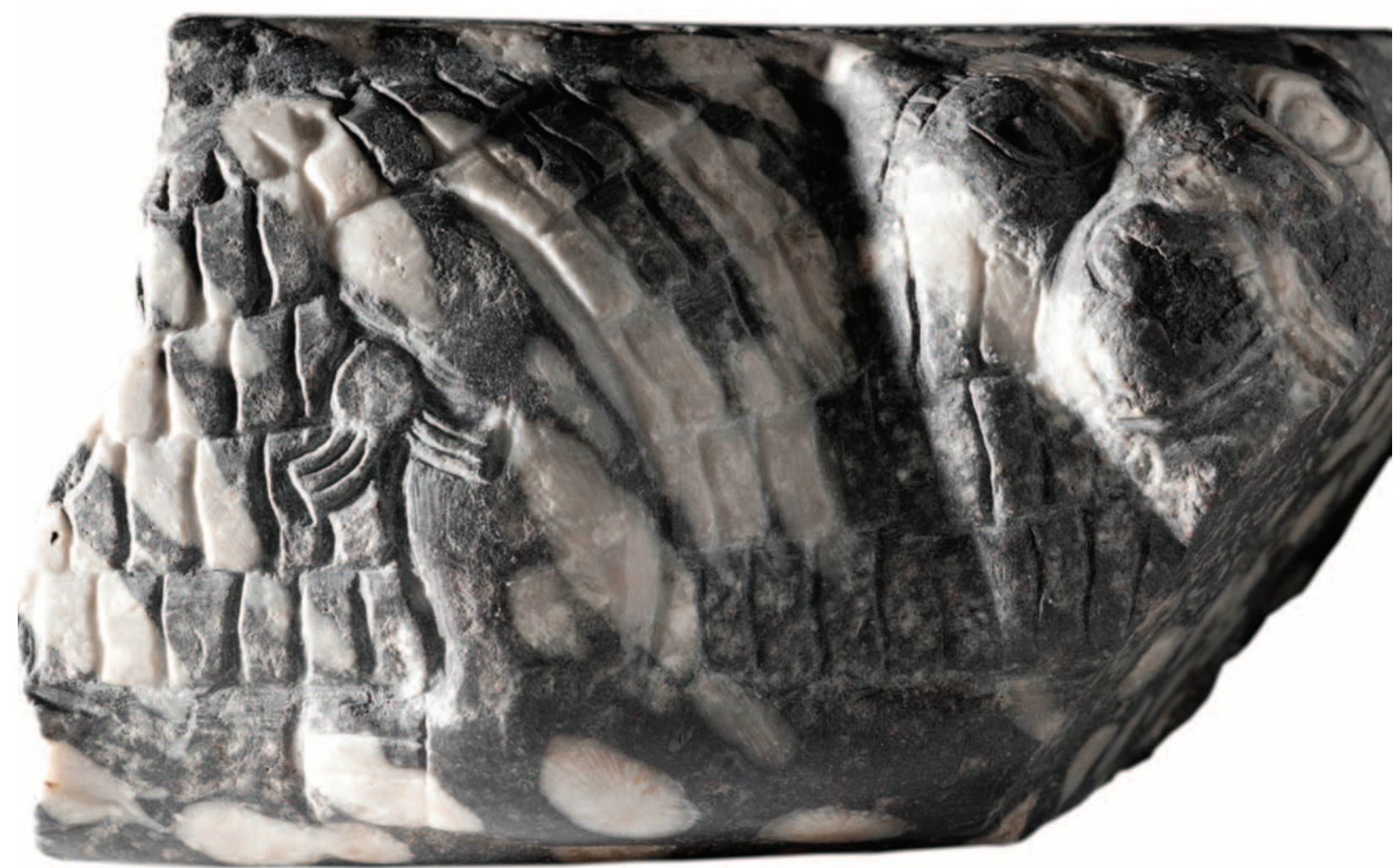

Figure 6-AO 153 - detail of the "winged disk" on the lion's rear shoulder (photo E. Loliva; courtesy Musée du Louvre). 


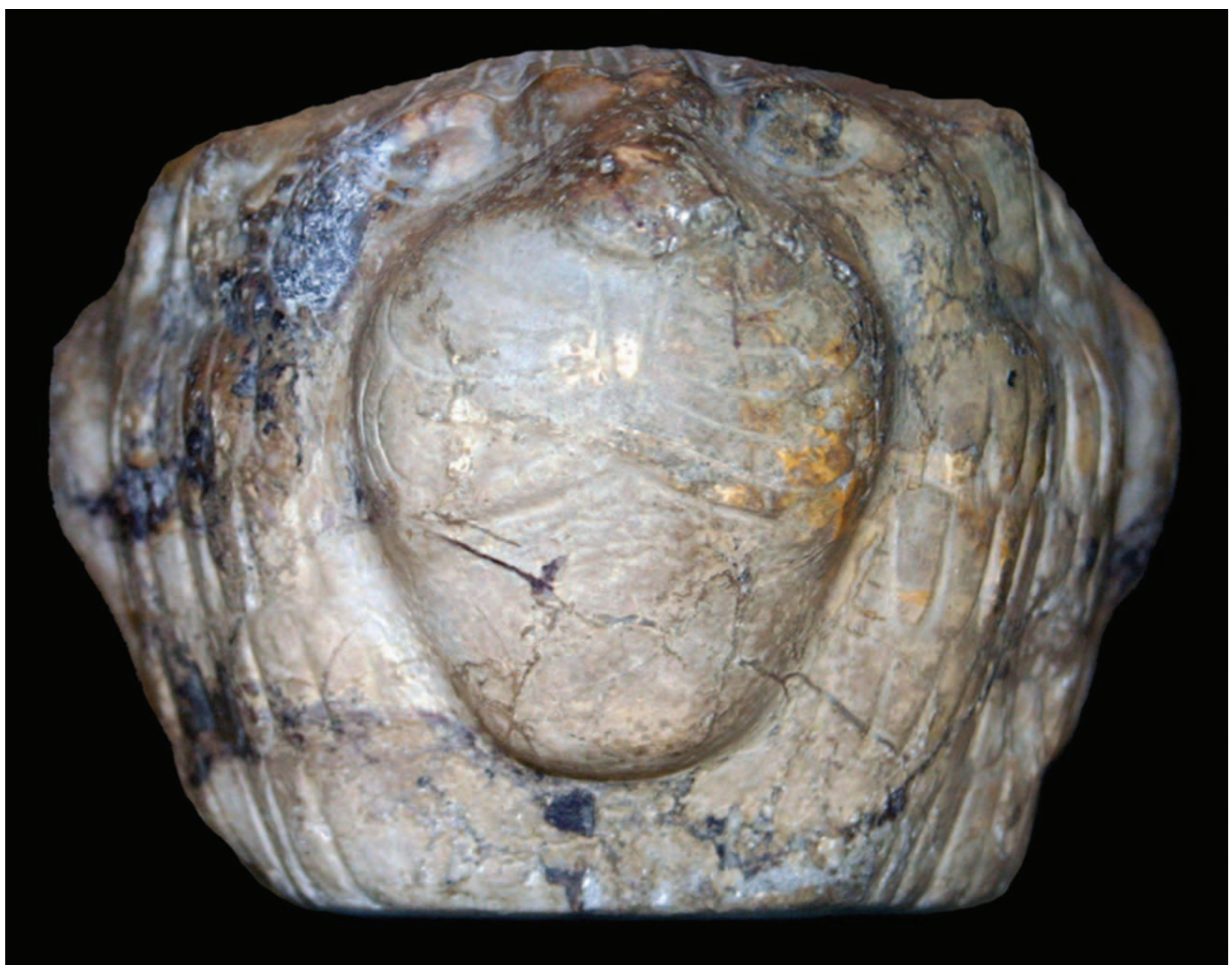

Figure 7-Gudea mace-head AO 133b (photo M. Vidale; courtesy Musée du Louvre).

\section{Stylistic Comparisons}

The lion of AO 153 closely resembles, in the muzzle and the rendering of the mane, the three lion's heads that decorate a votive mace-head dedicated by Gudea to the god Ninĝirsu (AO 133b; see Fig. 7). ${ }^{10}$ Both pieces can be ascribed to the same craft school or palace workshop. As far as the mane is concerned, we note the strong similarity of the basic geometry of the front muzzle, the double palmette-like pattern of the whiskers, and the band with incised traits in front of the ear. These standardized formal elements appear to have been quite influential in the following sculptural tradition, as they are still recognizable,

${ }^{10}$ Cf. de Sarzec and Heuzey, Découvertes, 229-30 and pl. 25 ${ }^{\text {bis, }}$, nos. $1^{\text {a }}-1^{\text {b}}$; Heuzey, Catalogue, 265, no. 117; Parrot, Tello, 196 and fig. 42h; Braun-Holzinger, Weihgaben, 53-54, K 48. although with modifications, in later temple guardian lions in terracotta. ${ }^{11}$

Another object that obviously belonged to the same cultural and religious milieu is the fragmentary basin AO 73 (Figs. 8-9), from the so-called "palais de Tello" (i.e., from Tell A, where once stood the Ninĝirsu temple built by Gudea). ${ }^{12}$ The object in question, dedicated to Ningirsu by Gudea, was described by Heuzey as follows:

${ }^{11}$ See, for instance, the Old Babylonian terracotta lion published by E. Peltenburg, The Burrel Collection: Western Asiatic Antiquities (Edinburgh, 1991), 65-67, no. 42, fig. 13 (here Fig. 12, No. 6), especially as regards the rendering of whiskers and the band of rectangles below the ear.

${ }^{12}$ De Sarzec and Heuzey, Découvertes, 231-32 and pl. 24, no. 3. Cf. Heuzey, Catalogue, 158, no. 39; Parrot, Tello, 195, 197, and fig. $42 \mathrm{k}$; and Braun-Holzinger, Weihgaben, 160-70, G 252. 
Journal of Near Eastern Studies

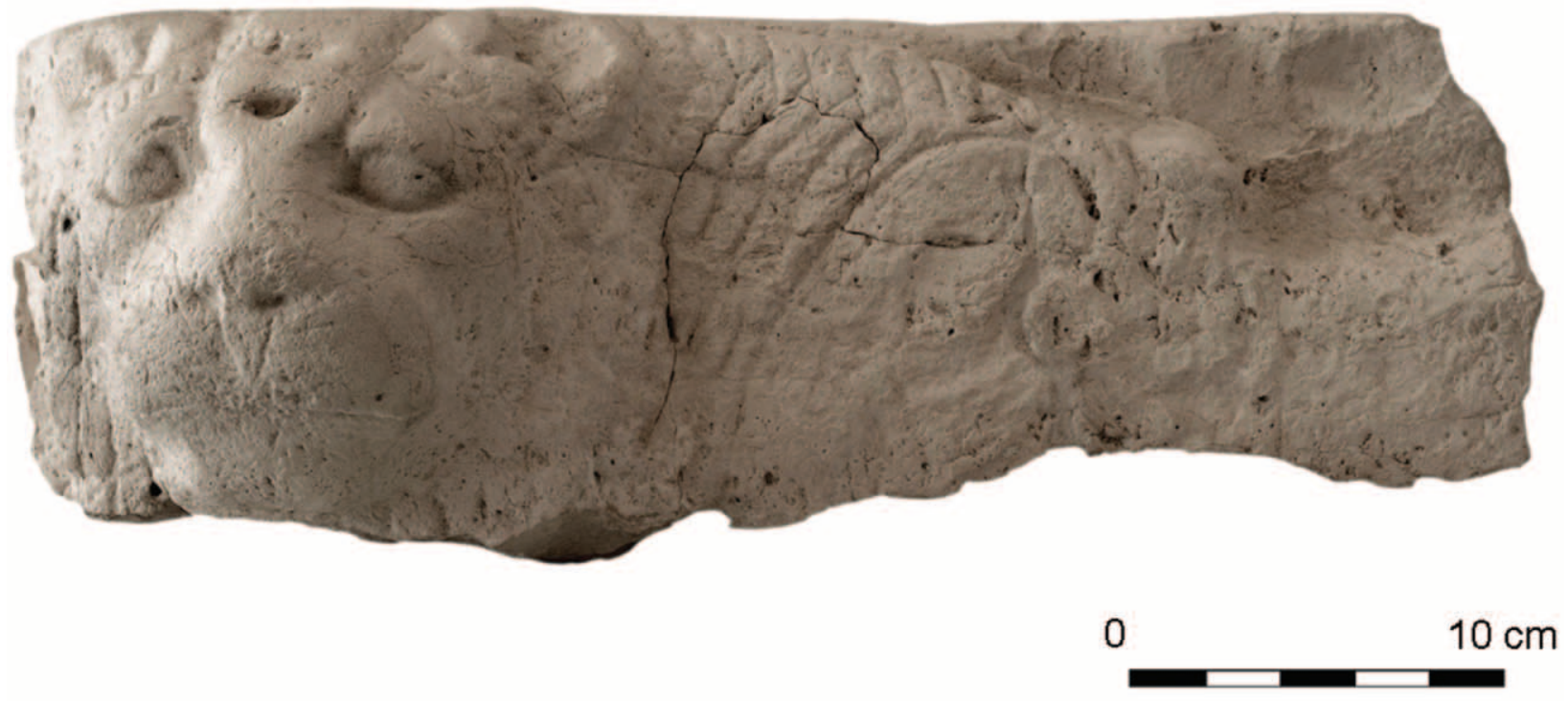

Figure 8-Fragmentary basin in white limestone AO 73-frontal view (photo E. Loliva; courtesy Musée du Louvre).

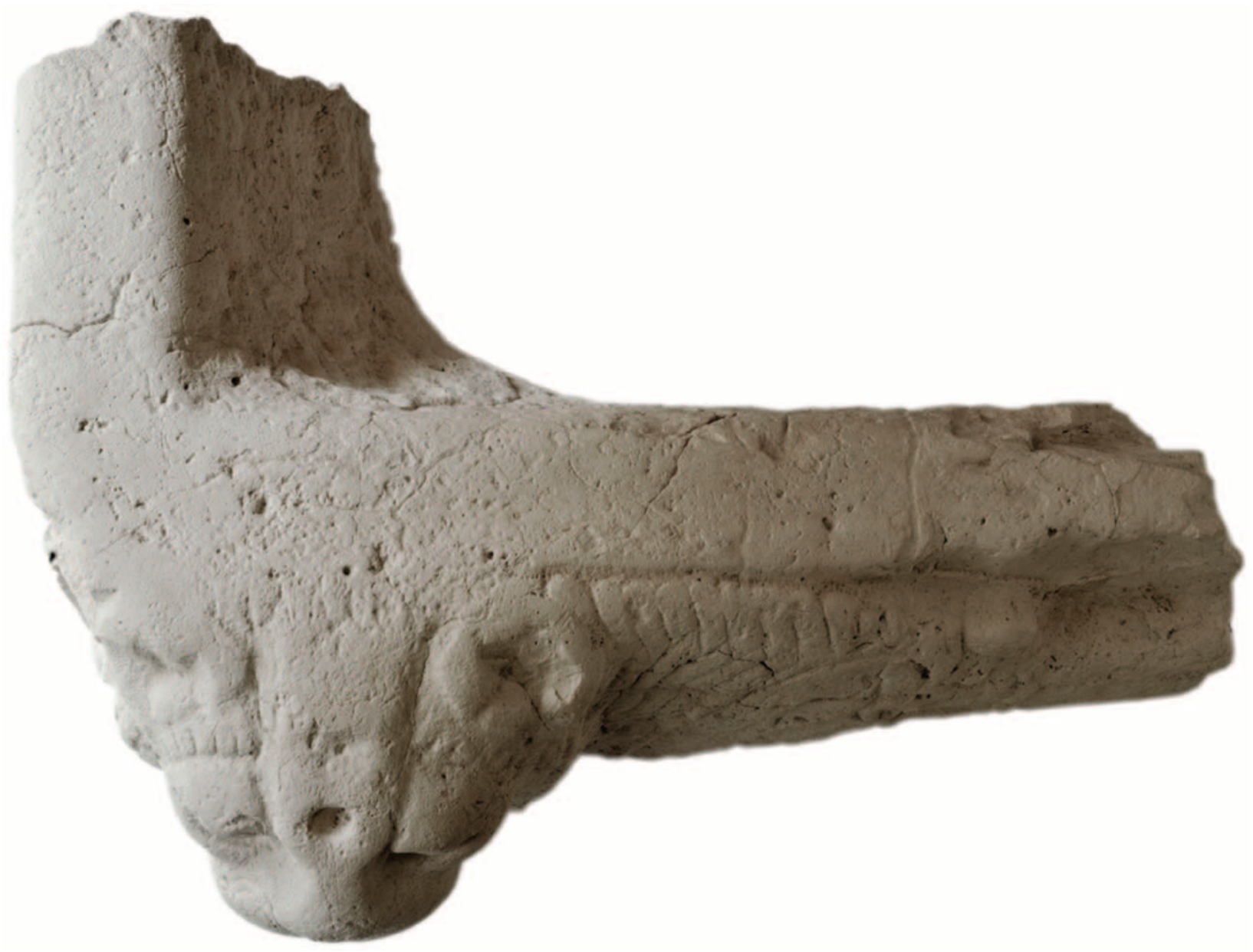

Figure 9-AO 73-zenithal view (photo E. Loliva; courtesy Musée du Louvre). 


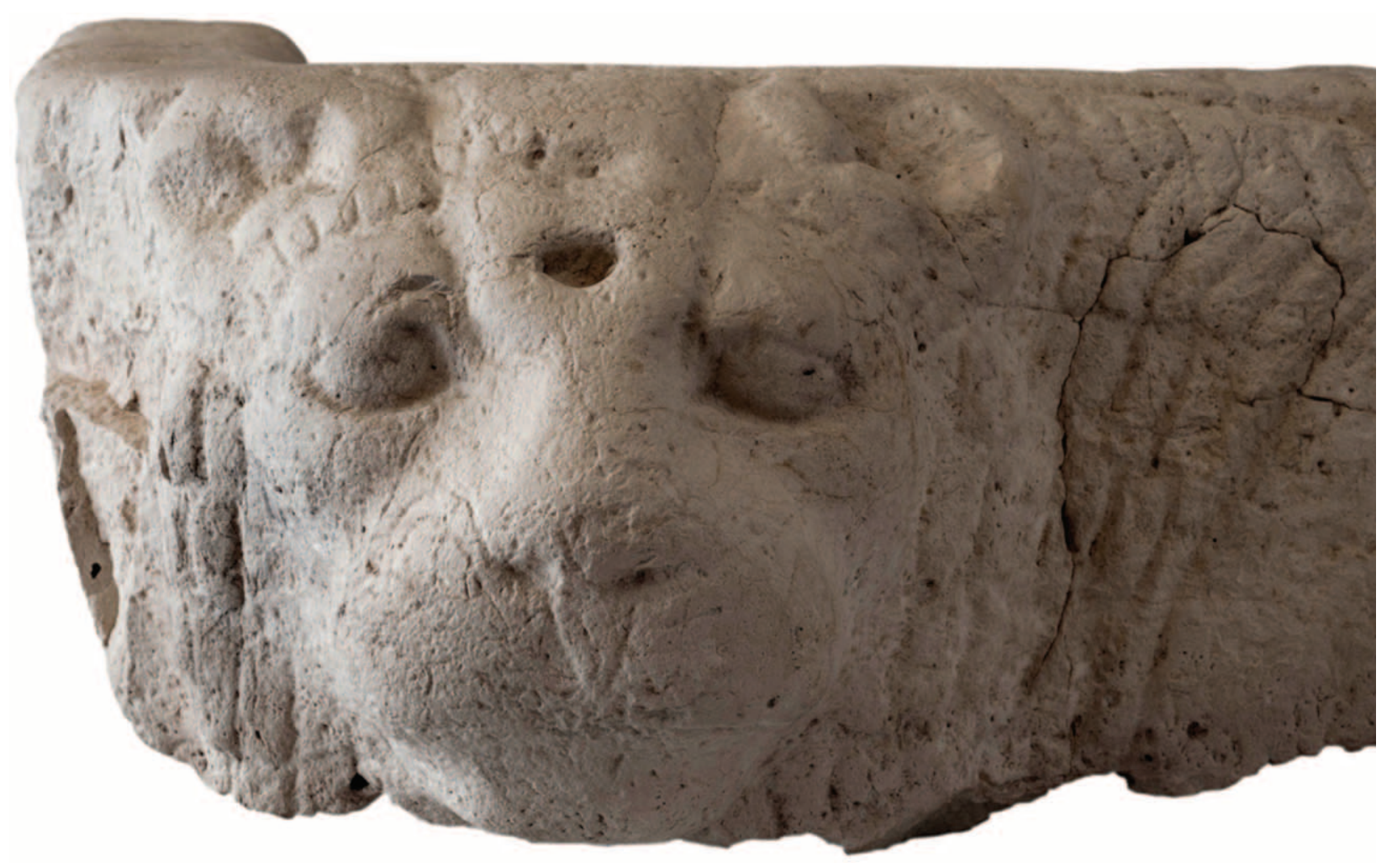

Figure 10-AO 73-detail of lion's muzzle (photo E. Loliva; courtesy Musée du Louvre).

... angle d'un grand bassin de forme rectangulaire, orné d'une belle tête de lion, ... les sillons du mufle, disposés en palmette, restent très apparents. . . . La tête se détachait de face et en plein relief vers l'angle du bassin, perpendiculairement à l'un de ses grands côtés, sur lequel elle était complétée par le corps tout entier de l'animal, sculpté à plat et se développant de profil; on y voit encore la crinière et l'épaule, d'un dessin large et vigoureux. Il devait y avoir deux lions ainsi placés en sens contraire et dont les têtes, se retournant à angle droit, formaient poignées aux deux extrémités, par une combinaison, à la fois très vivante et très décorative, de la ronde bosse et du bas-relief. ${ }^{13}$

The style of the lion's head of AO 73 (Fig. 10) closely links this sculpture to those of our dish and the abovementioned Gudea mace-head: identical are the mane, the forms of the inverted triangular nose-point, the double palmette-like whiskers, and the hatched band that encircles the head, interrupted by the sloping fore-

\footnotetext{
${ }^{13}$ De Sarzec and Heuzey, Découvertes, 231-32. Note that two additional minor fragments of lions' muzzles in the Louvre may have belonged to the same basin.
}

head..$^{14}$ In addition, the same iconographic motif, a sort of winged disk placed on the upper rear of the forelimb of the feline (Fig. 11), occurs on both AO 73 and AO 153. Finally, it should be noted that other Gudea lions display similar stylistic traits, especially as regards the rendering of the mane with regular rows of vertical rectangles suggesting lines of hair tufts. ${ }^{15}$ In summary, the formal and stylistic elements that $\mathrm{AO} 153$ appears to share with other sculptures of lions, or with lion imagery from the time of Gudea, support an attribution of this dish, too, to the lapidary workshops of Gudea's court. ${ }^{16}$

${ }^{14}$ Here the central hole, possibly meant to hold an inlay, has no parallel, however.

${ }^{15}$ See, especially, Fig. 12, No. 2c (after U. Finkbeiner, Uruk: Kampagne 35-37, 1982-1984. Die archäologische Oberflächenuntersuchung (Survey), Ausgrabungen in Uruk-Warka: Endberichte 4 [Mainz am Rhein, 1991], pl. 262 + detail from R. M. Boehmer, "Uruk-Warka XXXVII: Survey des Stadtgebietes von Uruk. VI. Kleinfunde," Bagh. Mitt. 16 [1985]: pl. 21). Cf. also the lion's head published in de Sarzec and Heuzey, Découvertes, pl. 24, no. 1, which is probably to be attributed to either Gudea or some other ruler of the so-called Second Dynasty of Lagash.

${ }^{16}$ This also agrees with the interpretation of the inscription on the rim of AO 153 as a Gudea inscription (see Marchesi, "Gudea and the Master of Lions," this issue of JNES). 


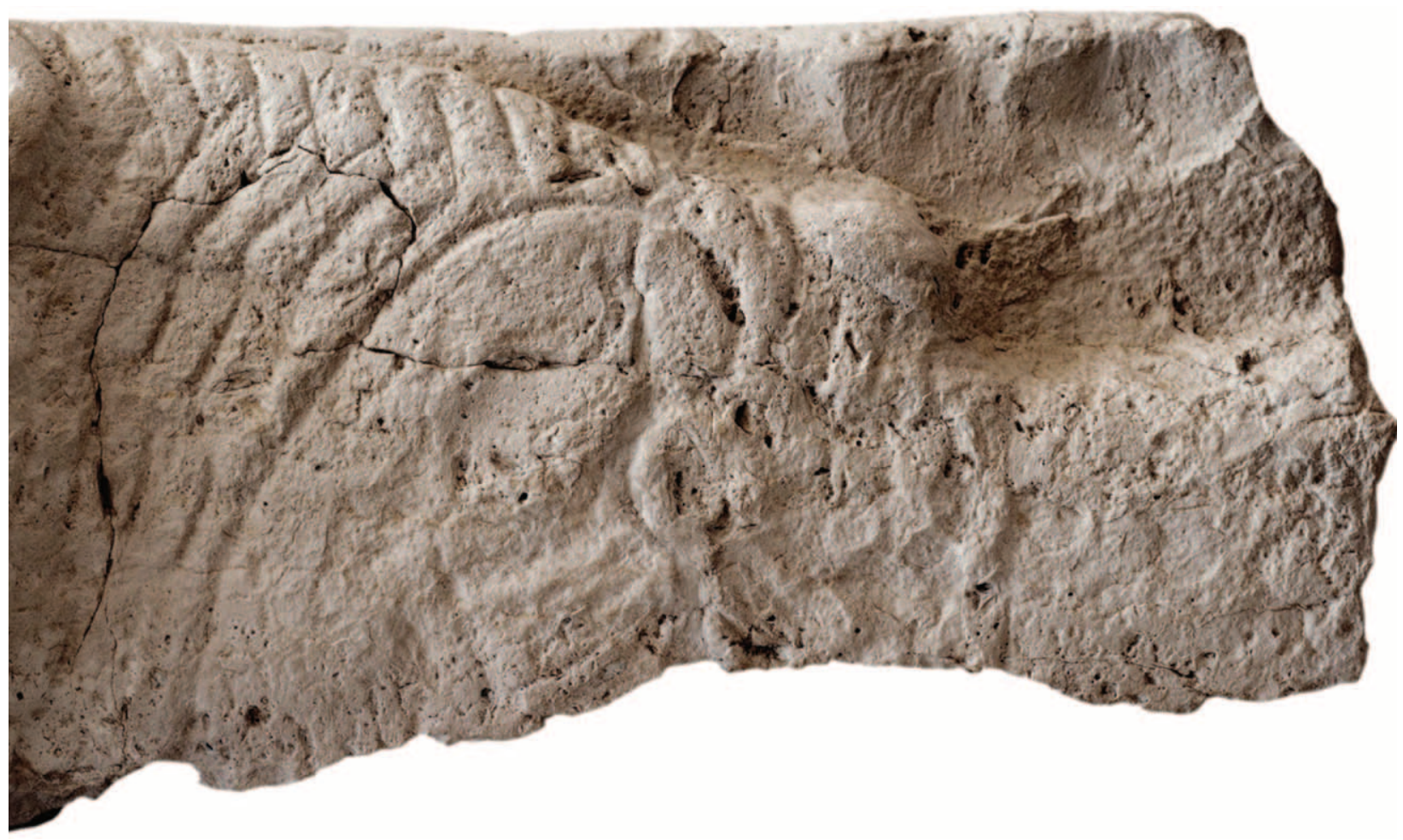

Figure 11-AO 73-detail of the "winged disk" on the lion's rear shoulder (photo E. Loliva; courtesy Musée du Louvre).

\section{The Lion's Shoulder Ornament}

This peculiar iconographic element, which we tentatively interpret as a winged disk, ${ }^{17}$ is well recognizable in the same anatomical position (the rear of the upper shoulder) on a series of Mesopotamian lion images dating from the Sargonic to the Old Babylonian periods. The earliest attestation is on a Sargonic seal in the collections of Columbia University, which shows a combat scene between a nude hero and a lion. ${ }^{18}$ The latter bears a simple disk with short parallel ra-

${ }^{17}$ Cf. already A. Vollgraff-Roes, "The Lion with Body Markings in Oriental Art," JNES 12 (1953): 41-42. On the other hand, P. Amiet, L'art d’Agadé au Musée du Louvre (Paris, 1976), 38, described it as "un ornement en forme de nœud qui tient la place de celui qui a la forme d'une hélice"; while according to Collon, Queen of the Night, 34-35, the element in question looks like a "drooping bow or moustache." But it actually represents a hair whorl (similarly D. Beyer et al., "Les lions du temple du 'Roi du Pays' de Mari," MARI7 [1993]: 103, who interpreted it as a "touffe de poils tournoyants qui caractériserarjt certains fauves, particulièrement jeunes et vigoureux; cf. below, p. 82 and n. 30). See also P. Albenda, "The 'Queen of the Night' Plaque-A Revisit," JAOS 125/2 (2005): 186.

${ }^{18}$ E. Porada, "The Oldest Inscribed Works of Art in the Columbia Collections," Columbia Library Columns (February 1964): 25-33. diating lines on the shoulder (Fig. 12, No. 1). ${ }^{19}$ The same motif with well-developed, slightly bent lower appendages is then found in several Gudea artifacts (Fig. 12, Nos. 2a-2c) $2^{20}$ on the lions of a statue of a goddess (the so-called Narunde) from Susa (on the back and on the sides of the throne, as well as below the feet of the deity; see Fig. 12, No. 3); ${ }^{21}$ on a

${ }^{19}$ After Porada, "Oldest Inscribed Works of Art," 33 and R. M. Boehmer, "Uruk-Warka XXXVII," 144, fig. 5 (drawing by C. Haase).

${ }^{20}$ In addition to AO 73 (No. 2a) and AO 153 (No. 2b), discussed above, there is a lion statue, found at Uruk, which bears a Gudea inscription (No. 2c; see n. 15 above).

${ }^{21} \mathrm{Sb} 54$ (body) + Sb 6617 (head) (photos E. Loliva; courtesy Musée du Louvre). Cf. Amiet, L'art d'Agadé, 38-39 and figs. 36a-e; A. Spycket, La statuaire du Proche-Orient ancien, Handbuch der Orientalistik 7.1.2.B.2 (Leiden, 1981), 144-45 and pl. 96; P. O. Harper, J. Aruz, and F. Tallon, The Royal City Of Susa: Ancient Near Eastern Treasures in the Louvre (Paris, 1992), 90-91, no. 55. Goddess with a four-fold horned crown, holding a palm leaf and a goblet. The statue bears two inscriptions, one in Linear Elamite and one in cuneiform writing in Akkadian; see I. J. Gelb and B. Kienast, Die altakkadischen Königsinschriften des dritten Jahrtausends vor Chr., Freiburger Altorientalische Studien 7 (Stuttgart, 1990), 335-36, Elam 10. It should be noted that the usual interpretation of this piece as an image of the goddess Narunde (or Narunte) rests 


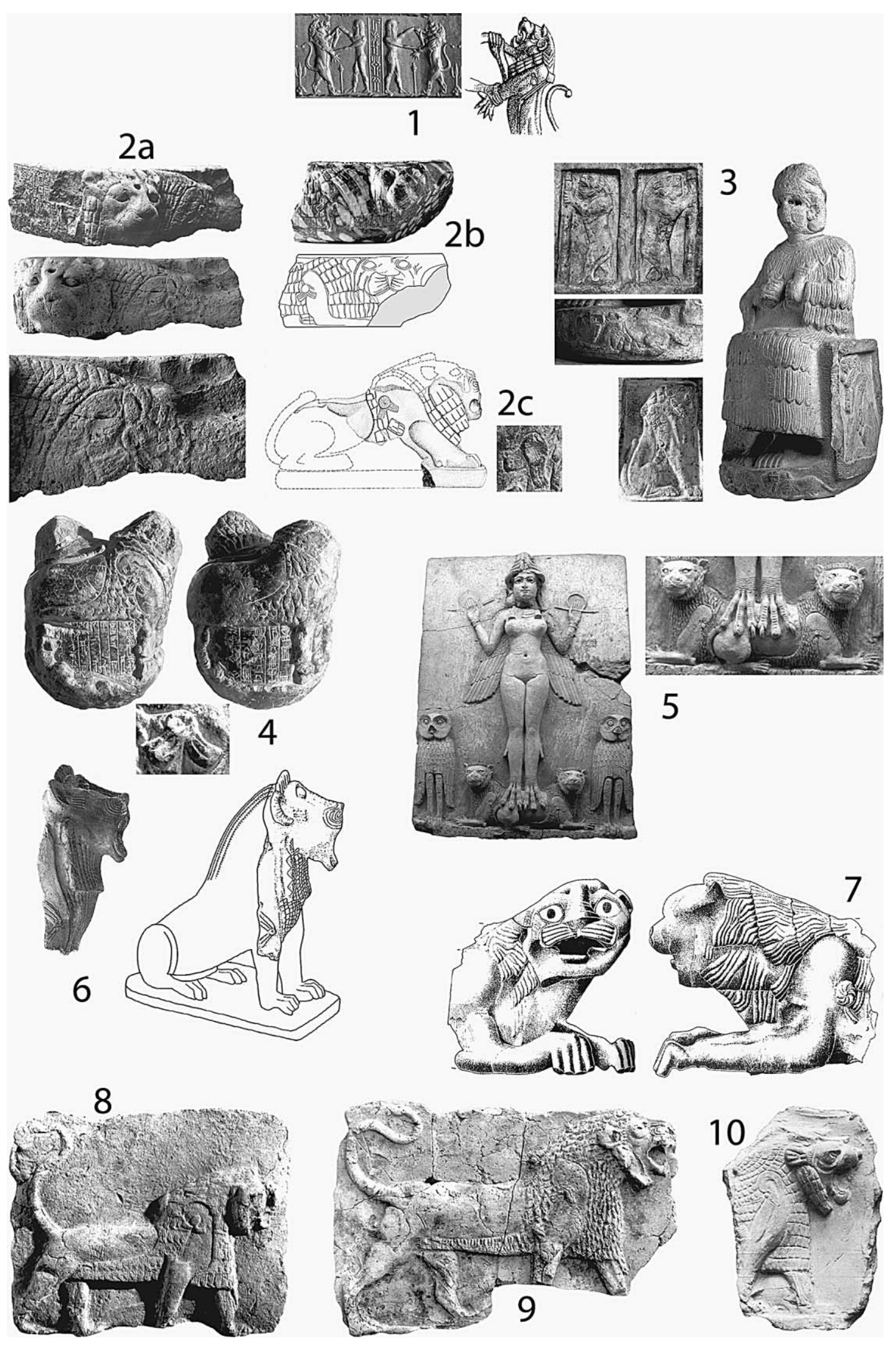

Figure 12-General illustration of artifacts displaying the "winged disk" (references in the text). 
mace-head with two lions dedicated for the life of king Sulgi of Ur, which also comes from Susa (Fig. 12, No. $4) ; 22$ on the lions below the goddess of the Burney Relief (the upper edge of the circle crowned by a set of short spiralling traits; see Fig. 12, No. 5),23 and on a terracotta guardian lion dating to the Isin-Larsa or Old Babylonian period in the Burrell Collection at Glasgow (Fig. 12, No. 6). ${ }^{24}$ Later variants of the same motif are visible on a copper lion statue from Mari (Fig. 12, No. 7), ${ }^{25}$ and in some Old Babylonian terracotta plaques depicting lions inceding in profile (Fig. 12, Nos. 8-10). ${ }^{26}$

Shoulder ornaments on lions in Egyptian and Near Eastern artworks of different periods were studied by H. J. Kantor. ${ }^{27}$ According to Kantor, the motif had a long and complex history, spreading from Egypt eastwards; she suggested that it may have originated from "a geometric ornament applied to live lions of

only on the alleged occurrence of her name in the Linear Elamite inscription, which, however, is far from certain (cf. W. Hinz and H. Koch, Elamisches Wörterbuch [Berlin, 1987], 993, s.v. na-ru-un-te). While the Linear Elamite script still awaits deciphering (see, most recently, F. Desset, Premières écritures iraniennes: Les systèmes protoélamite et élamite linéaire [Napoli, 2012], 93-127), some iconographic details, such as the eight-petaled rosette on the pedestal of the statue and the associated lions, point to a representation of the Mesopotamian goddess Innana/Ištar instead (cf. R. Mayer-Opificius, "Eine Ischtardarstellung aus Tell Dscharablus-Tachtani," in About Subartu: Studies Devoted to Upper Mesopotamia, 2: Culture, Society, Image, ed. M. Lebeau, Subartu 4/2 [Turnhout, 1998], 281-82). According to Moortgat-Correns, Mesopotamia, 143, both inscriptions were secondary (that is, later additions by the Susian king Puzur-Insusinak; see also R. M. Boehmer, "Die Datierung des Puzur/Kutik-Inšušinak und einige sich daraus ergebende Konsequenzen," Or. 35 [1966]: 355), and she suggested that the statue could have been brought to Susa as a spoil of war.

${ }^{22}$ Sb 2745 (photos F. Desset; courtesy Musée du Louvre). Cf. V. Scheil, Textes élamites-sémitiques: Cinquième série, MDP 14 (Paris, 1913), 22; and P. Amiet, Elam (Auvers-sur-Oise, 1966), 244, no. 177.

${ }^{23}$ See $\mathrm{n} .7$ above.

${ }^{24}$ See $n .11$ above.

${ }^{25}$ Adapted from Beyer et al., "Lions," 94, fig. 8.

${ }^{26}$ After, respectively, G. Ligabue and G. Rossi Osmida, Animali e mito nel Vicino Oriente antico (Trebaseleghe, 2008), 198, fig. 1; and D. E. McCown and R. C. Haines, Nippur I: Temple of Enlil, Scribal Quarter and Soundings, OIP 78 (Chicago, 1967), pl. 142, nos. 10 and 8. In the "Ligabue" lion (also published by M. F. Fales, Prima dell'alfabeto: La storia della scrittura attraverso testi cuneiformi inediti [Venezia, 1989], 136), the "winged disk" has a rather peculiar shape, with the "wings" under the disk.

${ }^{27}$ H. J. Kantor, "The Shoulder Ornament of Near Eastern Lions," JNES 6 (1947): 250-74. the court and copied in reliefs," ${ }^{28}$ and that it developed to assume the form of a "hair star," possibly under the influence of actual spiral-like tufts on bulls. ${ }^{29} \mathrm{~A}$ problem with Kantor's arguments is that she freely grouped in the same discussion quite different markings and symbols, such as dotted circles, dots, whirls, stars, and rosettes. It should be stressed that none of the motifs she discussed has the wing-like appendages.

Kantor's idea of a long diffusion from Egypt of a motif originally inspired by an actual ornament was opposed by zoologists and consequently by several archaeologists and art historians. They made clear that the torsional motif depicted on the shoulder of lions is actually a natural hair feature of male cubs and young lions up to three years old, before being covered by the mane of fully grown individuals. ${ }^{30}$ Our shoulder motif-though different and more complex - was likewise interpreted as a representation of a hair whorl. ${ }^{31}$

Still other explanations have been put forward: A. Vollgraff-Roes proposed that it was a solar symbol instead. ${ }^{32}$ She realized the specific formal identity of a smaller set of Mesopotamian "winged disks," which "look like nothing so much as like the winged sun disk." ${ }^{33}$ Finally, W. Hartner suggested that the motif in question is a star-symbol denoting the "celestial" lion, that is, the constellation of Leo. ${ }^{34}$

Fig. 13 summarizes the variations in time of the "winged disk" from its early occurrence in the Sargonic period (Fig. 13, No. 1), when the motif is abstract and fully inorganic, to the times of Gudea and the Ur III Dynasty (Fig. 13, Nos. 2a-c, 3, and 4) when the "wings" are clearly expressed, and sometimes combined with a whirl. This whirl is still clearly

${ }^{28}$ Ibid., 254.

${ }^{29}$ See also H. J. Kantor, "A Further Comment on the Shoulder Ornament," JNES 9 (1950): 55-56.

${ }^{30}$ A. J. Arkell, "The Shoulder Ornament of Near Eastern Lions," JNES 7 (1948): 52; D. M. A. Bate, "The 'Shoulder Ornament' of Near Eastern Lions," JNES 9 (1950): 53-54; E. D. van Buren, "An Additional Note on the Hair Whirl," JNES 9 (1950): 54-55. The shoulder hair whorl is well illustrated in a picture of a young lion in ibid., pl. II (after p. 54).

${ }^{31}$ See Beyer et al., "Lions," 101-103; Collon, Queen of the Night, 34-35, and "The Queen under Attack-A Rejoinder," Iraq 69 (2007): 49.

${ }^{32}$ A. Vollgraff-Roes, "The Lion with Body Markings," 40-49.

${ }^{33}$ Ibid., 41-42.

${ }^{34}$ W. Hartner, "The Earliest History of the Constellations in the Near East and the Motif of the Lion-Bull Combat," JNES 24 (1965): 3-4 with n. 11. 

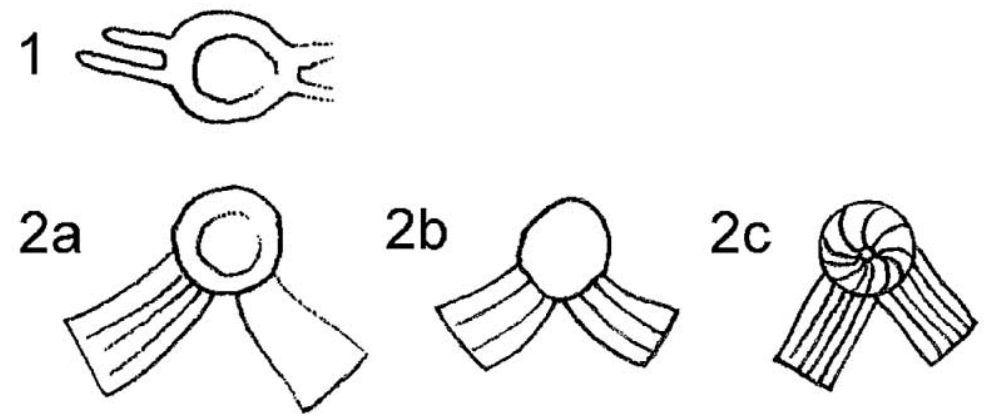

3
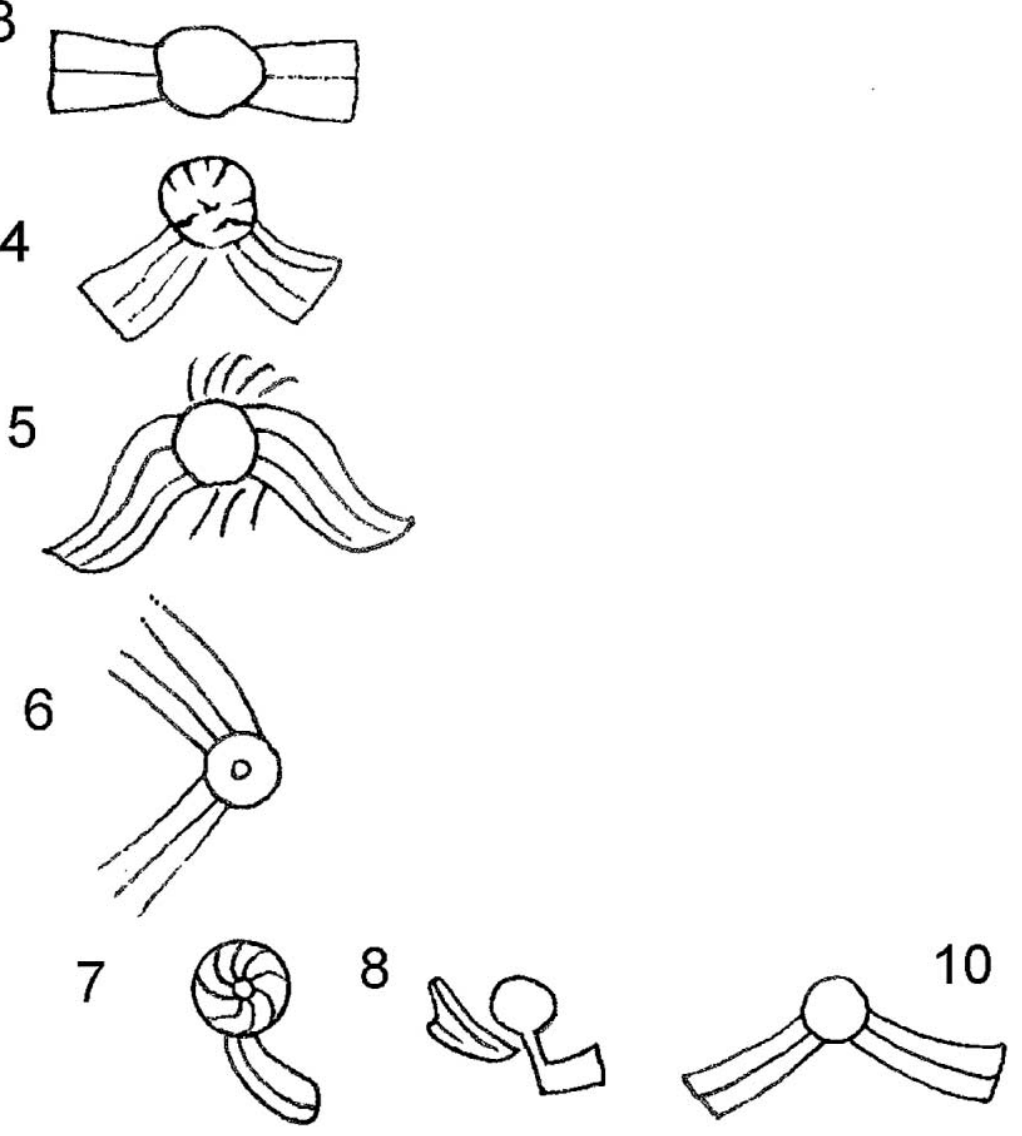

Figure 13- "Winged disks" drafted from Fig. 12, 1-8, 10.

recognizable on the edge of the "winged disk" in the lions of the Burney relief (Fig. 13, No. 5).

The evidence we have collected here suggests a formal evolution across the time span of some centuries: from a simple radiating circle to a more complex whirl with a central dot, with symmetrical wing-like appendages. It seems that in the course of time a radiant or winged circle merged with the representation of a distinctive hair whorl visible on the fur of young lions. In Old Babylonian times, however, our motif seems to be in the process of losing its symmetry and merging with the tufts of the mane, perhaps because the pattern had been replicated beyond recognition (see especially Figs. 12-13, No. 7, with the "winged disk" changed into a sort of cockade).

At any rate, because of the appendages, which might have been conceived as supernatural wings, this emblem should be treated separately from the more common and widespread hair whorl motives, which were and remained for a long time naturalistically 
inspired. At present, we cannot exclude that symbolic wings attached to the shoulder disks might have given an astral nature to guardian lions and lions portrayed on cultual objects; the shoulder mark might also have identified a specific supernatural lion, fighting with mythological heroes, and linked, at Lagash, to the divine sphere of Ninĝirsu. ${ }^{35}$

\section{Concluding Remarks}

As this exceptional artifact shows, among the imports of exotic stones by the court of Gudea were also large raw blocks of Waagenophyllum coral limestone, most probably coming from the eastern Iranian plateau. These were used to make cult objects in a distinctive and coherent local style. ${ }^{36}$ Thanks to its recurrent

35 See Marchesi, "Gudea and the Master of Lions," in this issue of JNES.

${ }^{36}$ For other inscribed artifacts made of Waagenophyllum coral limestone, see ibid.: as Marchesi points out, all the known examples conventional forms, such a style is well recognizable in a limited series of large and small sculptures representing lions. Emphasis on lion imagery, possibly charged with supernatural symbols, links these sculptures - perhaps made by a single family of craftsmen for a short period of time-with the cult and the local temple of Ningirsu. ${ }^{37}$ The aggressive stance of the larger guardian lions, crouching beside doors with wide open jaws, ${ }^{38}$ contrasted with the solemn, intent look of the same animals in smaller sculptures such as AO 153 and AO 73, whose purpose inside the sacred precinct was protecting, rather than threatening.

are related to the Second Dynasty of Lagash and date to a period of just two generations.

${ }^{37}$ See ibid.

${ }^{38}$ See Boehmer, "Uruk-Warka XXXVII," 142 and pl. 22. 